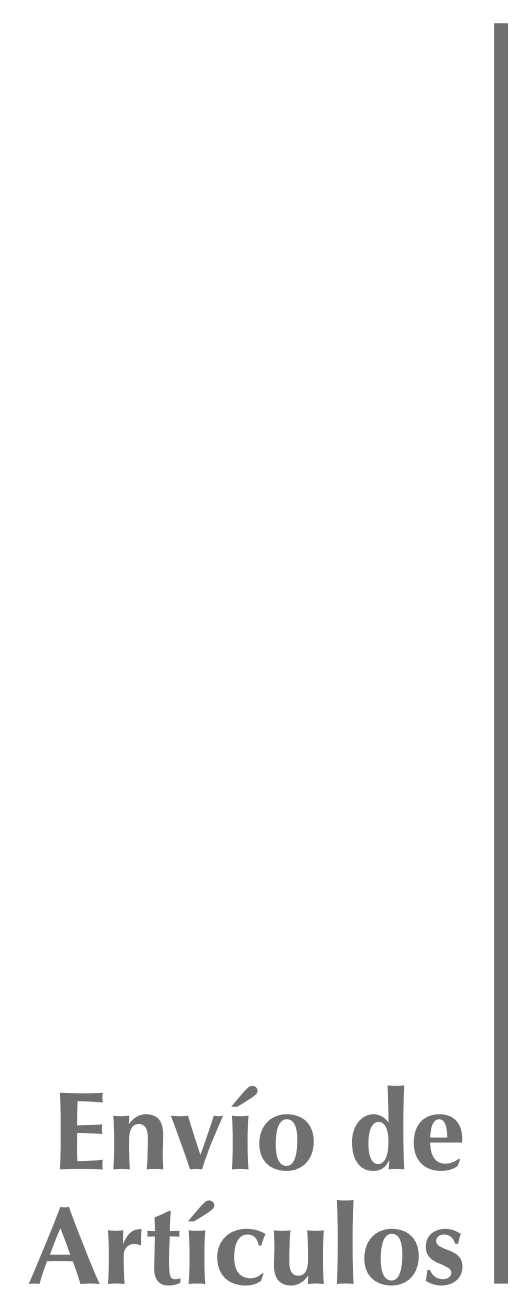





\section{Envío de artículos}

El Anuario de Derechos Humanos está recibiendo contribuciones para su próxima edición 2016. El Anuario se imprime en 500 ejemplares, se distribuye gratuitamente, y se encuentra además íntegramente disponible para su descarga gratuita en www.anuariocdh.uchile.cl.

Se recibirán artículos para las secciones Internacional y Nacional (Chile).

Estas secciones tienen por objetivo brindar información y análisis de los desarrollos relevantes en el campo de los derechos humanos ocurridos durante el año anterior a la publicación del Anuario.

La convocatoria que contiene los temas específicos a los cuales el Anuario dará prioridad para su publicación en 2016 se encontrará disponible en la página web del Anuario (www.anuariocdh. uchile.cl) y en la página web del Centro de Derechos Humanos (www.cdh.uchile.cl).

El plazo para el envío de contribuciones y sus requisitos se encontrarán en la misma. 
